\title{
Repression and Activism among the Arab Spring's First Movers: Evidence from Morocco's February 20th Movement
}

\begin{abstract}
ADRIA K. LAWRENCE*
Why are some people willing to initiate protest against authoritarian regimes? How does repression affect their willingness to act? Drawing on data from the Arab Spring protests in Morocco, this article argues first that activism is passed down from one generation to the next: first movers often came from families that had been punished for opposing the regime in the past. Secondly, repression during the Arab Spring was also counterproductive: those connected to first movers via Facebook supported renewed prodemocracy protests when informed of the regime's use of repression in 2011. A regime that jails and beats political dissidents creates incentives for its citizens to oppose it; these abuses can come back to haunt the regime long after repression occurs.
\end{abstract}

What happens when authoritarian regimes violate protesters' human rights by arresting, jailing or attacking them in the streets? Why are some people willing to initiate protest despite the threat of imprisonment and bodily harm? How does repression affect activists protesting authoritarian regimes?

The 2011 Arab Spring illustrates the variable effects of repression on protest. Tunisian dictator Ben Ali's rapid overthrow is widely attributed to the military's refusal to use force against protesters. ${ }^{1}$ In Egypt, military defection was also the regime's undoing. Egyptian police had used force to defuse street action for a decade. In 2011, they attempted to block protesters headed to Tahrir Square, but as the number of protesters swelled, the army refused to attack and Mubarak fell. ${ }^{2}$ In Bahrain, the military stood by the monarchy and brutally repressed peaceful protesters, crushing the movement. ${ }^{3}$ These cases point to the utility of coercive power for suppressing threats from the street: without it, regimes fall; with it, they hold onto power.

Yet the conclusions that can be drawn from Syria and Morocco are precisely the opposite. In Syria, the arrest and torture of graffiti-writing schoolchildren triggered protests in March 2011. Security forces cracked down, shooting and killing several unarmed demonstrators, and unleashing an escalating cycle of resistance and repression. ${ }^{4}$ In Morocco, the king was praised for eschewing severe repression; he rode out the protests by offering swift but minimal concessions, coupled with mild, selective repression. Syria and Morocco suggest that the use of force against unarmed citizens may be counterproductive for regime stability.

* Department of Political Science, Yale University (email: adria.lawrence@yale.edu). The author wishes to thank Leonardo Arriola, Lisa Blaydes, Nathan Brown, John Bullock, Daniel Butler, Julia Choucair, Thad Dunning, Amaney Jamal, Matthew Kocher, Timur Kuran, David Laitin, Audrey Latura, Luis Schiumerini, Susan Stokes, and participants at workshops at the University of California, Berkeley, Notre Dame University, Stanford University, Yale University and Tufts University. Data replication sets are available at http://dataverse.harvard. edu/dataverse/BJPolS and online appendices are available at http://dx.doi.org/doi:10.1017/S0007123415000733.

1 Bellin 2012, 130.

2 El-Ghobashy 2011.

3 Bellin 2012, 130.

${ }^{4}$ Leenders and Heydemann 2012, 142-3; Wedeen 2013, 855-6. 
It is widely acknowledged in the scholarly literature that repression can deter or encourage protest, but there is no consensus on how to correctly specify the relationship between the two. ${ }^{5}$ Attention to the type, targeting and timing of repression, as well as the organizational structure of state opponents, has added to our knowledge of the conditions under which repression inhibits or promotes protest. Yet further progress has been stalled by two challenges: difficulties in isolating the causal effect of repression, and insufficient attention to how different actors within a population respond to repression. ${ }^{6}$

This article uses three strategies to address these challenges. First, it examines repression that occurred in the distant past (and thus cannot have been caused by contemporary protest activity). Secondly, it draws on a survey experiment conducted on Facebook. Thirdly, building on the insight that repression can affect individuals within a population in different ways, this study disaggregates by targeting a critical subset of the population: first movers - those who organize and attend the initial protests - and their social networks.

By focusing on first movers, I depart from the existing literature, which mainly studies the conditions under which protests expand or contract. Yet the availability of first movers cannot be taken for granted. They are crucial to the success of mass protest because of the role they play in organizing and initiating it. Their behavior is puzzling because they act when the risks are high and the prospect of success is low. Since first movers are particularly likely to be repressed, it is important to understand how repression conditions their actions. If they are deterred from acting, mass protest is unlikely to occur.

My analysis draws on survey data and ethnographic fieldwork conducted during and after Morocco's Arab Spring. I suggest that regime repression in Morocco - specifically, the arrest or beating of political dissidents - encouraged first movers and their friends to participate in or support anti-regime protest. I argue first that activism is passed down from one generation to the next: the 2011 first movers often came from families that had suffered at the hands of the regime. Specifically, many first movers had family members who had previously been imprisoned for political activities. The effect of a family history of political imprisonment is mediated through prior mobilization into social movement organizations. Those whose families were repressed and who subsequently joined an organization had both the will and the ability to initiate protest when the Arab Spring began in the region. Secondly, I propose that the repression of protesters during the Arab Spring altered attitudes toward protest. Information about the regime's efforts to brutally police protests produced support for new protests among those with social ties to first movers.

These findings have important implications for understanding collective action. They help to link past, current and future episodes of protest. They suggest that repression can be consequential over both the long and short term. Decades-old human rights violations can motivate later generations to confront a regime even when most people are unwilling to do so. Repressing first movers can then increase support for protest among their friends and colleagues. Their support matters because those with social ties to first movers are likely to mobilize next; they are potential 'second movers' whose participation may induce others to join.

The rest of the article proceeds as follows. The next section discusses existing work on repression and first movers. Then the case selection and sampling procedure are described.

${ }^{5}$ Lichbach (1987) provides an overview of hypothesized relationships; Davenport and Moore (2012, 705) note that since Lichbach's review, 'we are remarkably little better informed about the extent to which the impact of repression on dissent tends to take one of these forms over the others, or why'. For other characterizations of the literature, see Earl (2011); Davenport (2005, 2007); Francisco (1995); McAdam, Tarrow, and Tilly $(2001,69)$.

${ }^{6}$ Davenport and Moore 2012, 708; Pierskalla 2010, 118. 
After the empirical evidence is presented, the conclusion considers the broader empirical and theoretical implications.

\section{LITERATURE AND THEORY}

This section discusses the challenges facing existing work on the relationship between repression and dissent. It then addresses the literature's insights about first movers. Despite their importance for collective action, there is little systematic consideration of what motivates first movers, and even less examination of the effects of repression on their willingness to act.

\section{Repression and Dissent}

Identifying the impact of repression on protest presents a thorny problem. ${ }^{7}$ Both the policing of protest and protest itself are endogenous processes; it can be difficult to assess whether brutal police action is a cause or consequence of protest. $^{8}$ A research design that compares cases with and without repression is vulnerable to omitted variable bias: unobserved factors may cause both protest and repression. At the individual level (the focus here), an ideal research design would compare those who were repressed with those who were not but who differed in no other relevant way, and examine downstream political behavior. Yet there are good reasons to expect that individuals who are targeted for repression differ systematically from those who are not. They may, for instance, be repressed because of their group membership or prior activities, factors that are also likely to affect their political behavior. Experimental approaches are difficult to employ because there are few examples of repression occurring in an as-if random fashion, and directly manipulating repression is both impractical and unethical. ${ }^{9}$

In addition to the general problem of identifying causal effects, the consequences of repression may vary across individuals living in the same country, spurring some to opposition and cowing others into submission. ${ }^{10}$ Thus researchers examining the overall response of a population may arrive at erroneous conclusions about the consequences of coercion. Attention to interaction effects is vital because some categories of actors play particularly important roles in generating collective action. Following Davenport and Moore's call to disaggregate actors, ${ }^{11}$ this study narrows the scope to a particular subset of individuals: first movers and their social networks.

\section{First Movers}

First movers are people who plan, publicize and initiate anti-regime protest. They are, by definition, crucial for starting street protests in authoritarian regimes, but there are few systematic explanations for their behavior. Inattention to first movers can be attributed to the

7 See Carey 2006; Davenport 2005, 2007; Pierskalla 2010, 118; Tilly 1978.

${ }^{8}$ States may also employ repression in anticipation of dissent (Danneman and Ritter 2014).

9 To identify the impact of collective punishment in civil war, Kocher et al. (2011) employ instrumental variable analysis and Lyall (2009) takes advantage of a rare situation in which repression can be argued to have occurred as if randomly. Ritter and Conrad (2013) use rainfall as an instrument to estimate the effects of dissent on repression.

${ }^{10}$ Gupta, Singh, and Sprague $(1993,302)$ attribute the absence of scholarly consensus on the effects of repression to mediating factors. For example, scholars have found an association between regime type and the impact of repression (Albertus and Menaldo 2012; Bellin 2004, 2012; Escribà-Folch 2013; Gupta, Singh, and Sprague 1993; Opp 1994; Pierskalla 2010). Rasler (1996) finds that repression's effects depend on timing. Aytaç et al. (2015) find that the effects of repression vary according to individuals' political affiliations. Opp and Reuhl (1990) argue that the effects of repression depend on whether its use is seen as legitimate.

11 Davenport and Moore 2012, 708. 
turn toward analyzing the structural factors instead of individual decision making. ${ }^{12}$ Structural changes are important because they provide opportunities for protest. Yet opportunities cannot be seized unless someone is waiting to seize them. Prior studies note the importance of first movers, but tend to study how they recruit others, not why they themselves mobilize. ${ }^{13}$

The assumption that first movers are readily available may stem from the observation that they are often already mobilized before a protest cycle begins. McAdam argues that social movement leaders are typically well integrated into their communities and involved in existing organizations before the onset of mass protest. ${ }^{14}$ They do not move from inaction to high-risk contention, but build on prior activism. Yet the question of why they mobilized in the first place remains puzzling, particularly in authoritarian regimes, which discourage and restrict political opposition.

Some theories imply that first movers constitute a personality type: a small percentage of courageous or altruistic people may simply be extraordinarily willing to take risks for a worthy political cause. ${ }^{15}$ Kuran posits a range of preferences among individuals in authoritarian states. He argues that early movers find it more difficult psychologically to hide their opposition to the regime than most people do. Thus they are willing to protest even when there are few other participants. ${ }^{16}$

The reasons why first-mover preferences differ remain opaque. Assuming that they have an unusually strong aversion to inaction or a courageous personality type is not theoretically satisfying. ${ }^{17}$ After all, while some individuals are naturally daring, there are many ways to take risks without participating in politics. Their behavior is difficult to explain; they engage in contentious action before most people are willing to do so, accepting the risks of collective action before any pay-offs can be anticipated.

The following empirical section uses qualitative field research to develop hypotheses about first-mover motivations. It considers three non-mutually exclusive hypotheses:

HYPOTHESIS 1: First movers have a stronger desire for regime change than others.

HYPOTHESIS 2: First movers come from a different demographic.

HYPOTHESIS 3: First movers have different prior political experiences.

Consistent with Hypothesis 3, I suggest that first movers are shaped by their prior experiences of repression and activism.

\section{CASE SELECTION AND SAMPLING PROCEDURE}

On 20 February 2011, Moroccans took to the streets in over fifty towns. The protests grew for several months, peaking in April 2011 when 110 towns experienced mass protests. ${ }^{18}$

12 Skocpol (1979) advocated a focus on structure. See McAdam et al. (2001) on the importance of political opportunity structures for protest.

${ }^{13}$ For example, Bueno de Mesquita 2010. Alternatively, first movers may be 'political entrepreneurs' who directly benefit from leadership (see Popkin 1989; Schneider and Teske 1992), but in authoritarian settings, the risks often outweigh the benefits, and future benefits are uncertain since the probability of success is unknown.

14 McAdam 1999, 47; see also McAdam et al. 2001, 52; Oberschall 1973; Opp and Roehl 1990, 526; Staggenborg 1991; Tarrow 1994.

${ }^{15}$ Lynch (2011) notes the courage of early movers in Egypt; Weyland $(2012,304)$ describes the commitment of the Arab Spring's first movers. On emotions as a cause of participation, see Jasper (2011, 920); Petersen (2002); Wood (2003).

16 Kuran 1991.

17 McAdam (1999) criticizes an earlier literature that focused on the personal pathologies of participants.

18 Benchemsi 2014. 
These were among the largest Arab Spring protests in the places where the ruler held onto power. The monarchy responded in three stages. At first, protests were tolerated; the regime attempted to minimize participation by denouncing the organizers on state media and refusing to authorize demonstrations. Secondly, the king signaled his willingness to meet the protesters' demands, announcing plans for constitutional reforms shortly after the protests began. The third strategy was targeted repression: in May, riot police beat protesters with truncheons; in subsequent months, pro-regime thugs harassed protesters. Over the course of the year, the regime detained and arrested protest leaders; some received prison sentences for criticizing the police and state. $^{19}$

The Moroccan case is useful for exploring the question of first-mover motivations in several respects. First, there is variation in the independent variable of interest; repression was applied to some protesters as part of the regime's mixed strategy, and its use varied over time. Repression took the form of arrests and police brutality, exceedingly common responses to protest in authoritarian regimes. ${ }^{20}$

Secondly, the absence of regime change makes it easier to identify and study first movers. In cases where mass mobilization overthrew the regime, it can be challenging to differentiate between first movers, late movers and non-participants because of the incentive to over-report participation. The Arab Spring cases pose an additional difficulty because protest groups deliberately sought to remain leaderless. Across cases, some first movers were well known; others became media figures during the protests, while yet others kept a low public profile. Even when first movers are identifiable, however, it remains difficult to discern their initial motives because their accounts may be affected by their later success. In Morocco, there is no heroic revolutionary discourse to guide a first mover's story. Both participants and non-participants are willing to be identified and to discuss their decision-making process. Moroccan first movers are also identifiable because they were not brutally wiped out; despite arrests and harassment, many remain active. ${ }^{21}$ Research on first movers is facilitated by the absence of either spectacular success or failure.

Prior studies of social movements have been criticized for studying only participants, but selecting non-participants is difficult. Identifying an appropriate counterfactual group for first movers requires careful consideration; it cannot easily be achieved through random sampling. Even the most successful social movements typically mobilize only a small fraction of the underlying population, meaning that a random sample would likely contain few protesters and even fewer first movers, who are an unusual group. A random sample of Moroccans, for instance, would likely include a large number of respondents who neither participated in 2011 nor had the opportunity to do so. ${ }^{22}$ These non-participants do not provide a useful counterfactual; they differ from first movers along multiple dimensions, such as age, location and education.

A more theoretically useful comparison is between first movers and those with a high potential to mobilize. Interviews and a survey instrument were designed to compare the first

19 Benchemsi 2014.

${ }^{20}$ In contrast, shooting demonstrators or engaging in collective punishment exemplifies extremely severe repression, which is visible in cases like Syria and Iraq under Saddam Hussein. See Blaydes (2014); Heydemann (2013); Makiya (1998) on the exceptional brutality of these regimes.

${ }^{21}$ One potential disadvantage of interviewing activists in a place where the regime stayed in power is that it may be risky to discuss participation. My interviews were conducted anonymously to protect interview subjects; pseudonyms were assigned.

${ }^{22}$ In rural areas, few were aware of the 2011 protests, according to a local academic (Field notes, January 2012). 
movers who initiated the 2011 protests to 'likely participants' who were as similar as possible to first movers, apart from their decision not to initiate protests. By identifying and sampling a counterfactual population, this research design follows the logic of a case-control design, which is widely used in epidemiology to compare groups with different outcomes on the basis of a hypothesized causal variable. This design is used when the outcome is rare or it is impossible or unethical to randomize the treatment variable. For this study, both conditions hold: first movers are scarce, and individuals cannot be randomly assigned to experience repression. Doll and Hill's study of the link between smoking and lung cancer is a prominent example of a casecontrol design; it was criticized because of the absence of random assignment to treatment and control groups. ${ }^{23}$ The limitations of case-control studies (as well as other types of observational studies) for demonstrating causality are well known, ${ }^{24}$ but they are useful when little is known about the relationship between a risk factor and a particular disease, as the cancer study suggests. In social science terms, this design focuses on the 'causes of effects' over the 'effects of causes', and has the virtue of identifying previously unexplored explanatory factors that can be included in future research designs. ${ }^{25}$

To create a counterfactual group, I sampled activists' social networks. From prior scholarship, we know that networks are crucial for mobilization; most people join a political movement via their networks. ${ }^{26}$ Yet not everyone in a network participates. I interviewed and surveyed first movers from the February $20^{\text {th }}$ Movement (M20), along with their friends, classmates and colleagues. These respondents were aware of the movement, they heard appeals to mobilize and they had personal connections to activists. They shared similar backgrounds. Using activists' social networks produced three kinds of actors: first movers, participants who attended a few protests and non-participants. The next section presents the empirical evidence.

\section{EMPIRICAL EVIDENCE}

This section describes the qualitative data used to generate and refine my hypotheses, draws on survey data, and reports on a survey experiment designed to evaluate how repression affects the occasional participants and non-participants who are linked to first movers on Facebook.

\section{Qualitative Evidence}

I conducted field research in Morocco from September 2011 to March 2012, primarily in Rabat. I participated in the activities of the M20, the primary protest organization, conducted fifty interviews, and engaged in online discussions with activists and non-participants.

Nabil, a blogger and member of the M20, helped organize the initial protest. His description of the atmosphere on the eve of the first demonstration illustrates the risks first movers face:

\footnotetext{
About twenty of us spent the night before the march downtown, at the headquarters of the l'Association Marocaine des Droits Humains (AMDH). We went over logistics. And we wondered what would happen the next day. The state had announced on television that the march was canceled, and had attempted to discredit those of us organizing it [...] I had no idea what the morning would bring. Would anyone show up? Would we arrive only to be immediately arrested?

23 Doll and Hill 1950; Fisher 1957.

24 See Breslow 1996; Schulz and Grimes 2002.

25 Gelman and Imbens 2013.

26 Gould 1991; McAdam 1999; Petersen 1993; Snow et al. 1980.
} 
I tell you, we did not sleep. In the morning, it was raining, and we all said, there it goes, no one will show up now. But it cleared up at $10 \mathrm{am}$, and little by little, the crowd grew [...] I never thought that we'd get Moroccans out in 60 towns. 60 towns! The next day, we went back to the AMDH headquarters and convened our first General Assembly to plan our strategy. ${ }^{27}$

As Nabil's account suggests, there was no way to predict participation in advance; the protest could have been limited to the small network of activists, leaving them vulnerable to arrest. It took courage to plan and attend. Even if they were not repressed, Nabil and his companions had other ways to spend their time; they did not need to personally absorb the costs of collective action. Their behavior is puzzling: they not only organized the 2011 demonstrations, but also continued to mobilize after the protest wave had crested. What led them to act?

The protests that erupted on February $20^{\text {th }}$ built on prior activism. After King Hassan II died in 1999, his son, King Mohammed VI, declared the 'years of lead' over and created the 'Equity and Reconciliation Commission' to look into the abuses of his father's regime. ${ }^{28} \mathrm{He}$ dismissed his father's minister of the interior, Driss Basri, who was responsible for imprisoning, torturing and even disappearing dissidents, and promised a more tolerant political environment. Political freedoms such as the right to free speech were not guaranteed, however, and the regime used a variety of tools to harass the emerging independent press and civil society associations. Still, a budding civil society sector began to emerge. Small street protests, which occurred rarely during the Hassan II era, were visible on a regular basis. Unemployed university graduates have demonstrated in the capital every Friday since 2005, for instance.

When protests began in Tunisia, many Moroccan first movers had already been discussing economic problems and the regime's exercise of power on a Facebook page, 'Young Moroccans debate with the King'. ${ }^{29}$ These participants, along with a number of organizations, staged a sit-in to express solidarity with the Tunisian people. ${ }^{30}$ Then one organizer said, 'we started to ask ourselves, if it happened in Tunisia, why not here?" ${ }^{31}$ They moved to organize a nationwide protest, mobilizing in person and online. In a recruitment video, Moroccans from a variety of backgrounds looked into the camera and explained why they would take action on February $20^{\text {th }}$. The video went viral on YouTube. ${ }^{32}$

Organizers came from groups with distinct agendas: human rights organizations, leftists, Islamists from the banned Justice and Charity group, committed secularists like the members of MALI (Mouvement Alternatif pour les Libertés Individuelles), the Amazigh (Berber) movement and some unemployed graduates. ${ }^{33}$ Given that the causes these groups espoused were so diverse, demands were kept simple: organizers called for a democratic constitution and a new parliament.

Most first movers came from these nascent social movement organizations, which coalesced into the M20 following the success of the first protest. ${ }^{34}$ They were already challenging the authoritarian status quo before events in Tunisia and Egypt provided a propitious opportunity for

\footnotetext{
27 Interview, 10 February 2012. Interviews were conducted in Moroccan derija or French.

28 The inquiry was far from exhaustive; commission members were not given access to security service files (personal communication, member of the commission).

29 Interview, 2 February 2012. The discussion was not, in fact, with the king.

30 See Benchemsi (2014) for an account of the groups that formed the M20.

31 Interview, December 2012.

$32 \mathrm{http}: / /$ www.youtube.com/watch?v=mZm750joM0U.

33 Interview, 12 December 2011. They were initially joined by women's organizations, artists and political parties including the Socialist Union of Popular Forces and the Party of Justice and Development; these groups pulled back their participation after the king promised reform in March.

34 Interview, 12 February 2012.
} 
mass protest. How, then, did they begin their involvement in contentious politics? Why were they ready and willing to seize the moment when most Moroccans regarded politics with apathy?

As the interviews progressed, an apparent pattern emerged: many first movers came from families that had previously suffered at the hands of the regime for their political activities. Imane, for instance, is the daughter of a political prisoner who was arrested in the mid-2000s on bogus anti-terrorism charges. She was, as she put it, 'a direct victim of despotism'. ${ }^{35}$ She joined a human rights organization to secure her father's release; through the organization she met others who would later form the M20. For others, the abuse came during the Hassan II era. Meriam's father was a trade unionist who was arrested in the early 1970s. When her father died four years ago, 'it was my turn to take up the fight', she said. She joined MALI, a group seeking rights for women and homosexuals, and later became a core member of the M20. ${ }^{36}$ Nabil's father was a political prisoner for five years during the 1970s; he became involved in politics via Facebook, joining the youth discussion group and then mobilizing with the AMDH youth. Younes' family has fought for Amazigh rights since a 1967 revolt that Hassan II brutally put down; during the revolt, his relatives were repressed. Younes joined a group for Amazigh rights in middle school. When the Arab Spring began, the M20 and its pro-democracy platform became his primary focus. ${ }^{37}$

A family history of repression did not mean that families pushed these youth into activism. In fact, they were often warned away. One activist whose father had been punished said that his mother pleaded with him, stating that 'politics leads only to prison. ${ }^{, 38}$ Nabil initially lied to his parents about his participation because he knew they would be afraid for him. Moroccan political prisoners suffer torture and poor living conditions; the experience of repression did not send the message that it was easy to endure. ${ }^{39}$

The path these respondents took to becoming first movers during the Arab Spring began with their families' experiences of repression. The punishment their family members suffered gave them an acute awareness of the regime's injustices. They described a sense of obligation to 'do something' and so they joined organizations that advocated for specific causes, such as Amazigh, women's and prisoner's rights. Membership in these organizations generated ties to other activists and an organizational basis from which to plan and initiate mass protest when the Tunisian Revolution provided an opportunity. They moved from a less risky to a riskier type of collective action, a shift that may be easier than moving from inaction to action.

First movers whose family members were not repressed also shifted from lower-risk participation in civil society groups to risky protest leadership; but for them, this shift provided their first personal experience of the regime's coercive apparatus. Mounia, a university student in Rabat, was a member of a women's rights organization in her hometown. She joined her college friends, who were helping organize the initial protest. She reported, 'The first time I realized that two mukhabarat [secret police] were following me, I went cold. They would watch me come out of my house and try to intimidate me. But you get used to it. ${ }^{40}$ Moving from low- to high-risk activism can thus occur without a family history of repression.

${ }^{35}$ Interview, 22 January 2012.

${ }^{36}$ Interview, 13 February 2012.

${ }^{37}$ Interview, 7 February 2012.

${ }^{38}$ Interview, 1 February 2012

${ }^{39}$ Political prisoners continue to be subjected to brutality (see Amnesty International, http://www.amnestyusa. org/research/reports/annual-report-moroccowestern-sahara-2013). In May 2011, Rabat's M20 staged a protest against the torture of political prisoners at a secret detention center; they were dispersed with force. The M20 continues to demand amnesty using the slogan 'free koulchi' (everyone). Interviews; see also http://www. alarabiya.net/articles/2011/05/16/149353.html.

${ }^{40}$ Interview, 2 March 2012. 
The occasional participants and non-participants I spoke with typically agreed with the overall objectives of the M20, but they did not have political prisoners in their families and were not already members of organizations. Kamal, age 24, participated with friends a few times in 2011 , but does not belong to an organization. He supports democratization and sees protest as a potentially effective tool, but says, 'I go when I can. I have other things I need to do. ${ }^{41}$ Similarly, Mohammed is a self-described secular leftist who attended three protests. He agrees with the M20's goals, but doubts they can achieve real change. Hussein agreed, saying, 'Probably nothing will come of these protests. Besides, I'm lazy. ${ }^{42}$

These examples suggest that it is not divergent views that separate first movers from others in their networks. This is surprising, because when asked why they participate, first movers emphasized their commitment to democracy and their opposition to despotism, not their family history. Yet occasional participants and non-participants in their networks shared their political beliefs. It was not disagreement about political ends that separated first movers from others in their networks.

Interviews and participant observation served a theory-building role. A family history of imprisonment was not initially posited as a motivation for first movers, but it is relevant to the hypotheses outlined above. First movers did not favor regime change more than others (Hypothesis 1), but they were more willing to work for it because of their prior political experiences (Hypothesis 3). Specifically, a family history of repression encouraged some to join civil society organizations before the Arab Spring began; these organizations produced the first movers who would initiate the 2011 protests. The interviews did not support the claim that first movers came from a different demographic (Hypothesis 2) because they were compared to others with similar backgrounds. Survey data provide further evidence that a family history of repression is associated with protest leadership.

\section{Facebook Survey of Activist Networks}

I distributed an online survey to a non-probability sample via Facebook. Facebook has not yet been widely used by political scientists, but for this study it provided a way to target activist networks. The drawbacks of relying on survey data are well known; survey questions presuppose a particular way of thinking about events, and surveys do not facilitate trust building among investigators and respondents. ${ }^{43}$ This latter issue is particularly problematic for studies of authoritarian states. In Morocco, where protests are illegal, respondents need to trust that the state will not be able to obtain their responses and identify them. Fieldwork was crucial for mitigating these disadvantages; interviewees assisted with the survey's design and distribution. While in the field, interview subjects frequently 'friended' me on Facebook. We remained in contact online, and several provided feedback on the survey design. My contacts then publicized it by posting the survey link on Facebook, 'liking' the link and joining an 'event' that provided the link. ${ }^{44}$ These actions increased the visibility and trustworthiness of the

${ }^{41}$ Interview, 12 December 2011.

42 Interview, November 2011.

43 See Parkinson 2013.

${ }^{44}$ Facebook was the major online mobilizing tool of the M20, and activists typically sought to reach the widest possible audience by having the maximum allowable number of friends $(5,000)$. I posted the link on twelve contacts' walls (first movers and non-participants linked to first movers) bi-monthly, and encouraged my fieldwork contacts to join the event and 'like' the survey. I also sent the link via private messages to several hundred friends of core activists. Interview subjects were asked not to take the survey. Respondents were provided with a secure link to the survey, which was available in French and Arabic. 
survey: because a friend endorsed the link, it appeared less suspicious than if it had come via advertising. ${ }^{45}$

The link was available between June and September 2012 and yielded 160 completed surveys. The number was limited by the absence of an incentive, lack of interest or time, and concerns about answering sensitive questions online. ${ }^{46}$ Like protesters in Egypt and Tunisia, respondents were young, well educated and mostly male. ${ }^{47}$ As expected with a sample drawn from first-mover networks, respondents tended to be critical of the government; 84 per cent reported dissatisfaction with the government's performance.

Like the qualitative interviews, the purpose of the survey was to compare first movers to others who closely resemble them - not to sample randomly across the population. Protest participants are likely to be over-represented since they may be more motivated to take a survey about activism. Still, 55 per cent of the sample did not participate in the 2011 protests. ${ }^{48}$ I compared first movers to their friends who were occasional participants or non-participants. Comparisons across available covariates (age, gender, class and occupation) suggested that the participants were slightly older than non-participants, but were otherwise similar.

The survey included open-ended questions that asked respondents why they did or did not protest in 2011. Participants described their commitment to the movement's objectives. Non-participants' responses $(n=41)$ were more diverse; a few examples include:

'Lack of strong motivation.'

'I believe in peaceful change.'

'Violence against demonstrators and it won't serve any purpose anyway... there was no support from political parties and other movements as there was in Tunisia and Egypt.'

'I don't like to march, I like to write!'

'I don't believe it has any utility.'

'No security, fear of repression.'

'I have my future to build.'

'I don't live in the cities where protests take place.'

'Change will come from organizations, not from the street.'

'It doesn't really interest me.'

'I'm an artist and I express myself in my own way.'

'I settled for observing and noting what was happening.'

'Because of obligations and restrictions imposed by my career.'

45 Using Facebook advertising, Aytaç et al. (2015) report a click-to-completion rate of 2.5 per cent in Istanbul and 5 per cent in Sao Paulo; Samuels and Zucco (2012) report a 14 per cent completion rate in Brazil. For my survey, 53 per cent of those who opened the survey link completed it, indicating that a survey distributed by a friend may produce higher response rates than advertising. The total number who saw the survey link is unknown due to private Facebook algorithms, lack of information about when and how often potential respondents check Facebook, and overlap among the social networks of those who posted the link.

${ }^{46}$ Offering an incentive would require identifying survey takers; given fears about answering controversial political questions online, it could deter participation. A cover letter stressed that surveys were anonymous and untraceable to individuals, but there were no positive inducements to take the survey.

${ }^{47}$ For descriptive statistics, see the Appendix Table 1, which contrasts the sample with the representative national sample used for the 2006 Arab Barometer. See also Beissinger et al. (2013), who use a representative sample from Egypt and Tunisia. Importantly, there is not a single protest demographic; Beissinger et al. (2013) show that protesters in Tunisia and Egypt differed, as might be expected, given that the protests began in different areas in each country and participation was higher in Tunisia.

48 See Appendix Table 2. 
These rationales mirror insights from the social movement literature on the factors that limit collective action: the costs of participating relative to other activities that one could engage in, the belief that protest is futile and a lack of opportunity.

First movers differed in two ways. First, they had prior experience with collective action: 83 per cent of those with the highest level of participation (attended more than five protests in 2011) had prior protest experience. ${ }^{49}$ They also tended to belong to organizations such as the M20, unions and other NGOs.

Secondly, first movers were more likely to have a family history of repression. Respondents were asked whether a family member had experienced a past violation of his/her rights. Fortyfive ( 29 per cent) out of 155 responded affirmatively. This high percentage reflects a difference between the sample and the general population. The incidence of repression in Morocco is unknown, but the regime, even in the 1970s, did not widely abuse human rights. If we were to randomly sample the population, we would probably find that the number of respondents with a family member who had been repressed for political activities is quite low. A few affirmative answers were due to an idiosyncratic interpretation of the question. Respondents who answered yes were invited to explain; nine had interpreted the question to include an instance of petty corruption. I discounted those answers and kept only those that described a past experience of police brutality or imprisonment for political activity. ${ }^{50}$ Of those, the modal answer was that a relative had been arrested and imprisoned during the Hassan II era.

The survey data support the hypothesis that first movers came from families with a history of repression. Table 1 presents a cross-tabulation of participation in protest and family experiences of human rights abuse. The first movers are represented in the group that participates at the highest level; they organized the initial protests and continued to protest after participation started declining. The middle categories represent the occasional participants, who attended the first big protests in early 2011. A full 40 per cent of those who participated in more than five protests had a family history of repression, compared to 14 per cent of those who did not participate..$^{51}$

The survey data suggest that it is specifically a history of repression that matters, not a family history of activism in general. Those with activist parents were no more likely to participate than those whose parents were not activists. ${ }^{52}$ Activism did not appear to be a family trait; only those whose parents suffered for their political acts are over-represented among the protesters.

These results include members of activist networks; others outside these networks may respond differently to the same family history. Addressing this possibility requires a research design that begins from the independent variable, sampling those whose families were repressed and examining the conditions under which they do or do not join activist networks. The data

\footnotetext{
${ }^{49}$ See Appendix Table 3. Past participation was significantly associated with participation in $2011(\mathrm{p}<0.01)$. Hoffman and Jamal (2012) discuss the importance of past protest for the broader Arab Spring.

${ }^{50}$ Out of the 45 respondents with a family history of human rights violation, 28 provided a written explanation. Thus the analysis may include some respondents who answered affirmatively because they had an instance of minor corruption in mind. This reporting issue should produce a bias against finding an association between prior repression and protest participation; victims of everyday corruption (a commonplace occurrence in Morocco) are not expected to protest at high rates. Men reported a family history of repression more often than women did; they also account for eight out of nine of the responses that included an instance of petty corruption, suggesting that they may have been more likely than women to over-report violations by widening the definition. There were no other observed differences among those who did and did not report a family history of regime repression.

${ }_{51}$ These results hold using an ordered logit regression that controls for age, sex, schooling and father's occupation. See Appendix Table 4.

${ }^{52}$ See Appendix Table 5.
} 
TABLE 1

Violation of Family Member's Human Rights, by Participation

\begin{tabular}{lccccc}
\hline $\begin{array}{l}\text { Did a member of your } \\
\text { family experience a } \\
\text { violation of his rights? }\end{array}$ & $\begin{array}{c}\text { Never } \\
\text { participated }\end{array}$ & $\begin{array}{c}\text { Attended } \\
1-3 \text { protests }\end{array}$ & $\begin{array}{c}\text { Attended } \\
4-5 \text { protests }\end{array}$ & $\begin{array}{c}\text { More than } \\
5 \text { protests }\end{array}$ & Total \\
\hline No & $85.7 \%$ & $73.1 \%$ & $73.3 \%$ & $60 \%$ & $77.4 \%$ \\
& $(72)$ & $(19)$ & $(11)$ & $(18)$ & $(120)$ \\
Yes & $14.3 \%$ & $26.9 \%$ & $26.7 \%$ & $40 \%$ & $16.8 \%$ \\
& $(12)$ & $(7)$ & $(4)$ & $(12)$ & $(35)$ \\
Total & $100.0 \%$ & $100.0 \%$ & $100.0 \%$ & $100.0 \%$ & $100.0 \%$ \\
& $(84)$ & $(26)$ & $(15)$ & $(30)$ & $(155)$ \\
\hline \hline
\end{tabular}

Note: Chi-squared $\mathrm{p}<.05$.

suggest two factors that may mediate the impact of family repression on protest initiation. The survey included twelve respondents whose family members had been repressed, but who nevertheless chose not to mobilize during the Arab Spring. None of them belonged to social movement organizations before the Arab Spring. In contrast, those whose families were repressed and who belonged to an organization protested at the highest rates during the 2011 wave. As posited, the effect of family repression may depend on whether it leads to organizational participation before high-risk demonstrations begin.

Secondly, eight of the twelve were either government employees or their fathers were. Dependence on the state for a family's livelihood is a plausible reason to eschew protesting. ${ }^{53}$ This pattern did not hold for the dataset as a whole, however. Father's government employment was associated with non-participation only among those whose families were repressed. Postrepression, families who are offered employment may refrain from protesting, but given the small sample size, further testing is required to evaluate this claim.

The data provide initial support for the argument that past repression matters. The difference in the family histories of participants and non-participants is striking because these groups are otherwise quite similar. The survey sampled members of the same social networks. They shared a general dissatisfaction with political life, but first movers were already mobilized into organizations, and many of their families had been victimized by the regime in the past. A family history of repression is not the sole pathway to activism, but those with this history formed a substantial subset of the M20's first movers. Prior repression may generate a cadre of already-mobilized activists who are prepared to organize protests when an opportunity presents itself.

\section{Facebook Survey Experiment}

The previous sections argued that a family history of repression motivated a portion of Moroccan first movers, but they did not address how repression affects occasional participants or non-participants. The Facebook survey provided a platform to supplement observational data with an experimental manipulation designed to consider the effects of repression carried out during the Arab Spring on people who were networked to first movers.

53 Beissinger et al. (2013,8-9) discuss prior work that argues that dependence on the government for income should be negatively associated with protest, but they find that government employees participated in the Egyptian and Tunisian protests at high rates. 
Hypotheses and experimental design. Some non-participants I interviewed cited fear of repression as their main reason for non-involvement. Repression can also signal that success is unlikely, further dampening the desirability of taking to the streets. Yet repression may encourage protest by angering observers and heightening the perceived worthiness of the cause. My survey experiment aimed to evaluate how first movers' social contacts were affected by repression - did it make them more sympathetic to the cause, or further distance them from committed activists?

Other regime actions can likewise affect potential protesters in either positive or negative ways. The Moroccan regime used two strategies in addition to repression: it tolerated mass protest more than other Arab states, and it offered some concessions. Tolerance could encourage protest by lowering costs, or deter it by reducing grievances. Concessions included jobs for some unemployed youth; these could dampen protest by reducing grievances, or increase it by inducing others to seek similar concessions.

To test the effects of regime behavior on the demand for protest, respondents were randomly assigned to one of three treatment groups or a control group. Treatments included factual questions that informed respondents about the regime's use of repression, its relative tolerance compared to Syria and Libya, and its concessions to the unemployed (see Table 2) ${ }^{54}$ The control group did not see any cues.

After exposure to the treatment, subjects were asked whether they would favor new demonstrations for democratic reform. They indicated their level of support by dragging a slider between 'oppose' to 'support', with 'indifferent' marked in the center.

Results. Subjects in the repression treatment expressed significantly greater support for future protests than the control group. Figure 1 plots the difference of means between the treatment groups and the control group. The point values mark the difference in means between each treatment group and the control group; the bars represent confidence intervals. Although the mean level of support for future protests was higher in the three treatment groups than it was in the control group, the difference was statistically significant only for the repression condition. ${ }^{55}$

By chance, men were slightly over-represented in the repression treatment. I therefore compared the mean responses for each assignment group by gender; the means for men and women were nearly identical.

A secondary result helps explain why the repression treatment increased respondents' support for protest. Respondents were asked about the status of democracy in Morocco over the previous two years. Table 3 presents a cross-tabulation of their responses by treatment group. The majority of the control group reported no change in the level of democracy, as did 40 per cent of those reminded of the regime's relative tolerance of protest; 61 per cent of respondents in the concession treatment said that democracy had increased. More respondents in the repression treatment estimated that democracy had decreased than in any of the other groups.

This result suggests that the experimental manipulation succeeded in affecting respondents' assessments of the regime. Qualitative interviews and open-ended survey questions indicated that respondents generally believe that protest is a right to be protected, regardless of their own participation. When reminded of repression, 27 per cent of subjects in the treatment group reported a decrease in democracy. Their support for protest may reflect a sense that action is

${ }^{54}$ The set-up was influenced by Bullock (2011), who tests whether party cues affect Americans' policy views.

${ }^{55}$ See Appendix Table 6. 
TABLE 2 Experimental Questions

Repression During the demonstrations of the Arab Spring in Morocco in 2011, a number of Treatment 1 peaceful protesters were wounded or arrested by the police in several towns. For example, a young girl was struck with a policeman's baton when she had just arrived at a demonstration in Rabat, and in Safi, a young demonstrator died after a policeman accidentally pushed him off a roof. Did you know that the police sometimes use force against protesters?

Tolerance

Treatment 2

The international press praised the Moroccan state for its tolerant response to the 2011 demonstrations, unlike other countries (like Syria and Libya) where there have been violent confrontations. Did you know that the regime was more tolerant toward demonstrators?

Concession Treatment 3

After the February $20^{\text {th }}$ movement's demonstrations, the regime gave jobs to some unemployed graduates and promised more jobs for youths. Did you know that the demonstrations contributed to producing work for some of the unemployed graduates?

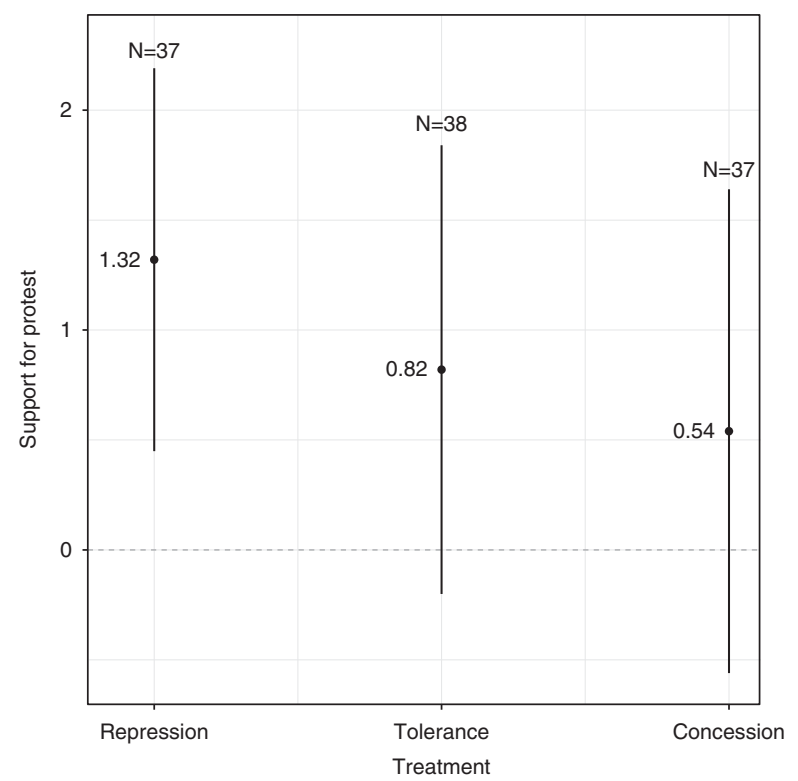

Fig. 1. Effects of cues on support for protest

Note: Difference of means between treatment groups and control group; lines represent 95 percent confidence intervals.

imperative because political conditions have worsened. ${ }^{56}$ Fewer respondents in the other assignment conditions said that democracy had declined; this may explain why they did not report a vital need for new protests.

Discussion. The finding that reminders of repression produced greater support for protest is surprising for three reasons. First, the $\mathrm{N}$ is small; for an effect to be significant, it has to be

56 Majorities in Morocco and the Arab world favor democracy and associate it with economic well-being (Jamal and Tessler 2008). 
table 3 Question Response: Do You Think Democracy in Morocco Has Increased over the Last Two Years?

\begin{tabular}{lccccc}
\hline \hline & $\begin{array}{c}\text { Repression } \\
\text { (Treatment 1) }\end{array}$ & $\begin{array}{c}\text { Tolerance } \\
\text { (Treatment 2) }\end{array}$ & $\begin{array}{c}\text { Concession } \\
\text { (Treatment 3) }\end{array}$ & Control & Total \\
\hline Yes & 15 & 17 & 25 & 12 & 69 \\
& $(34 \%)$ & $(40 \%)$ & $(61 \%)$ & $(32 \%)$ & $(42 \%)$ \\
No & 17 & 19 & 12 & 21 & 69 \\
& $(39 \%)$ & $(44 \%)$ & $(29 \%)$ & $(55 \%)$ & $(42 \%)$ \\
Less Democratic & 12 & 7 & 4 & 5 & 28 \\
& $(27 \%)$ & $(16 \%)$ & $(10 \%)$ & $(13 \%)$ & $(17 \%)$ \\
Total & 44 & 43 & 41 & 38 & 166 \\
& $(100 \%)$ & $(100 \%)$ & $(100 \%)$ & $(100 \%)$ & $(100 \%)$ \\
\hline \hline
\end{tabular}

Note: Chi-squared $\mathrm{p}=0.043$.

substantively large. Subjects in the repression treatment reported very high levels of support for protest; the median response of treated subjects was maximum support for renewed protest $(\mathrm{n}=26)$. Secondly, a non-random sample of activists and their friends (who chose to take a survey on political activism) are likely to already have strong opinions about popular protest, making them difficult to manipulate. Thirdly, it is likely that activists and their friends had already heard about repression and were therefore less susceptible to the treatment.

First movers comprise 29 per cent of the sample and they strongly support future protest, regardless of treatment assignment. ${ }^{57}$ The observed change occurs among respondents who did not already support future protests before taking the survey: it was the non-participants and occasional participants whose support shifted upward. ${ }^{58}$ This study may thus underestimate the effects of repression on those networked with activists; a sample excluding first movers might show a larger change in support.

These findings contribute to understanding the effects of repression on protest, but several caveats must be kept in mind. First, this study examined responses only within activist networks, but repression may affect others differently. Siegel posits that the effects of repression depend on networks; backlash occurs among those connected to people directly affected by repression. ${ }^{59}$ Outside those ties, repression may not generate support for protest.

Secondly, the small sample size and use of a convenience sample limit this study's external validity. Other studies, however, lend support to the plausibility of the findings. Using both representative and convenience samples, Aytaç et al. find similarly that repression provoked backlash among those who shared the political affiliations of protesters in Turkey, Brazil and Ukraine. $^{60}$

Thirdly, this experiment tested the effects of repression on attitudes, not behavior. This is an intractable problem, given that attempting to manipulate participation would put subjects in danger at a time when protesters in Morocco faced arrests and beatings. Evaluating changes in support for protest remains important, however, because such changes can alter the perceived

\footnotetext{
${ }^{57}$ Disaggregating the data shows that first movers do not differ in their support for new protests across the assignment groups.

58 Albertson and Lawrence (2009) analyze a field experiment in which a subset of the treatment group was likely to already possess the opinions that the experimental manipulation sought to stimulate. The leverage in that study and this one comes from the effects of the treatment on those who are susceptible to new information.

${ }^{59}$ Siegel 2011.

${ }^{60}$ Aytaç et al. 2015.
} 
costs and benefits of opposing the regime. Further, the experience of first movers suggests a way in which support may be channeled into action. Above, I argued that past repression induced future first movers to join social movement organizations; this experience prepared them to take a leading role in 2011. The implication is that attitude change may translate into action only if organizations are able to take advantage of increased support by targeting sympathizers for recruitment. Repression may not induce non-participants to take to the streets, but it may increase their willingness to become politically active in less contentious ways, paving the way for future protest participation. Social movement organizations are aware that repression can generate sympathy and frequently publicize regime repression. Moroccan first movers post photos of activists who have been beaten or tortured on Facebook. My analysis suggests that there is utility in doing so.

\section{CONCLUSION}

This article identified one path to first-mover activism: a substantial number of Moroccan first movers' immediate relatives were political prisoners. This experience prompted them to engage in politics before the Arab Spring; when it arrived, they were ready to lead. The explanatory potential of this argument is broad. Prominent Arab Spring activists in other countries also came from families with a history of imprisonment for political activism - for example, Egypt's Alaa Abd El Fatah, Tunisia's Lina Ben Mhenni and Bahrain's Zainab Al-Khawaja. Alaa Abd El Fatah, writing on first movers in Egypt, describes multiple personal histories that can lead to activism, including 'witnessing injustice and being motivated either by its memory or by family lore on attempts to resist it. ${ }^{61}$ Members of the committees that formed to organize the rebellion in Dar'a, Syria often had a history of imprisonment. ${ }^{62}$ In Turkey, Kurdish children attribute their engagement in contentious acts to their parents' past experience of state violence. ${ }^{63}$ More broadly, this argument contributes to new research that suggests that personal experiences of victimization increase political participation. ${ }^{64}$

A cadre of motivated first movers is crucial for successful mobilization. Despite their importance, we know little about why they act. Their disregard for personal risk and willingness to bear high costs is far more difficult to explain than the behavior of followers who find safety in numbers. This article has sought to initiate theorizing about the factors that encourage the few who are willing to organize and instigate collective action in its early stages. It provides a testable causal logic for a phenomenon that may have multiple causes. Further research is required to assess the argument's applicability in other settings and to identify other pathways that produce first movers.

This article also identified a second effect of repressing activists: when told about police repression, first movers' friends increase their support for contentious acts. This finding is important because of the role that social networks play in mass protest. People who are networked to participants are particularly susceptible to mobilization. If repression generates support among first movers' friends, all else equal, their probability of mobilizing is likely to increase. Once they join, the movement is one step closer to triggering cascades of participation.

61 Personal communication, November 2013. El Fattah has also been repeatedly imprisoned; in June 2014, the al-Sisi regime sentenced him to 15 years in prison for organizing protests.

62 Leenders and Heydemann 2012, 147, 154.

63 Darıc1 2013.

${ }^{64}$ For examples, see Bateson 2012; Blattman 2009; Hersh 2013. 
Several characteristics of this study suggest both its limitations and its promise for future research. First, Moroccan activists were often beaten or imprisoned. This type of repression is extremely common, but other types may have different effects. The term 'repression' groups together vastly different regime tactics, from limits on free speech to violent collective punishment. There is little reason to expect these tactics to generate similar effects.

Secondly, the case-control design, with its focus on the 'causes of effects', compares similar participants and non-participants; it does not assess 'effects of causes', which would require starting with variation in family repression and following its consequences. The obstacles to such an approach are immense, but if it were feasible, it could provide an estimate of how often prior family repression leads to first-mover activism. ${ }^{65}$ My research does not estimate the effect of family repression in the general population; it focuses on an atypical subgroup. Heterogeneous effects are possible; repression could interact with other factors and deter rather than encourage those outside the networks sampled here from engaging in collective action. Future work to assess how and whether the effects of personal experiences of repression vary across population subgroups is a useful next step. Attention to how groups in different networks, locations and social classes respond to repression can help address unresolved theoretical and empirical questions.

\section{REFERENCES}

Albertson, Bethany, and Adria Lawrence. 2009. After the Credits Roll: The Long-Term Effects of Educational Television on Public Knowledge and Attitudes. American Politics Research 37 (2):275-300.

Albertus, Michael, and Victor A. Menaldo. 2012. Coercive Capacity and the Prospects for Democratization. Comparative Politics 44 (2):151-9.

Aytaç, S. Erdem, Luis Schiumerini, and Susan Carol Stokes. 2015. Why Does Repression Make Protests Grow? Behavioral Underpinnings of Backlash Movements. Working Paper. New Haven, CT: Yale University.

Bateson, Regina. 2012. Crime Victimization and Political Participation. American Political Science Review 106 (3):570-87.

Beissinger, Mark R., Amaney A. Jamal, and Kevin Mazur. 2013. Who Participated in the Arab Spring? A Comparison of Egyptian and Tunisian Revolutions. Working Paper. Princeton, NJ: Princeton University.

Bellin, Eva. 2004. The Robustness of Authoritarianism in the Middle East: Exceptionalism in Comparative Perspective. Comparative Politics 36 (2):139-57.

- 2012. Reconsidering the Robustness of Authoritarianism in the Middle East: Lessons from the Arab Spring. Comparative Politics 44 (2):127-49.

Benchemsi, Ahmed. 2014. Feb20's Rise and Fall: A Moroccan Story. In Taking to the Streets: Activism, Arab Uprisings, and Democratization, edited by Ellen Lust and Lina Khatib, 199-235. Baltimore, MD: Johns Hopkins University Press.

Blattman, Christopher. 2009. From Violence to Voting: War and Political Participation in Uganda. American Political Science Review 103 (2):231-47.

Blaydes, Lisa. 2014. Compliance and Resistance in Iraq Under Saddam Hussein: Evidence from the Files of the Ba'ath Party. Working Paper. Stanford, CA: Stanford University.

65 This is a hard-to-reach population; there is no registry of those who were repressed in the past. The difficulty of getting data on political prisoners in authoritarian contexts is only half the battle. In addition, we must assume that regimes do not repress randomly, but their selection process is unknown and difficult to estimate. 
Breslow, Norman E. 1996. Statistics in Epidemiology: The Case-Control Study. Journal of the American Statistical Association 91 (433):14-28.

Bullock, John G. 2011. Elite Influence on Public Opinion in an Informed Electorate. American Political Science Review 105 (3):496-515.

Carey, Sabine C. 2006. The Dynamic Relationship Between Protest and Repression. Political Research Quarterly 59 (1):1-11.

Danneman, Nathan, and Emily Hencken Ritter. 2014. Contagious Rebellion and Preemptive Repression. Journal of Conflict Resolution 58 (2):254-79.

Darıc1, Haydar. 2013. Adults See Politics as a Game: Politics of Kurdish Children in Urban Turkey. International Journal of Middle East Studies 45 (4):775-90.

Davenport, Christian. 2005. Introduction. Repression and Mobilization: Insights from Political Science and Sociology. In Repression and Mobilization, edited by Christian Davenport, Carol Mueller and Hank Johnston, vii-xli. Minneapolis: University of Minnesota Press.

—. 2007. State Repression and Political Order. Annual Review of Political Science 10 (1):1-23.

Davenport, Christian, and Will H. Moore. 2012. The Arab Spring, Winter, and Back Again? (Re)Introducing the Dissent-Repression Nexus with a Twist. International Interactions: Empirical and Theoretical Research in International Relations 38 (5):704-13.

De Mesquita, Ethan Bueno. 2010. Regime Change and Revolutionary Entrepreneurs. American Political Science Review 104 (3):446-66.

Doll, Richard, and A. Bradford Hill. 1950. Smoking and Carcinoma of the Lung. British Medical Journal 2 (4682):739-48.

Earl, Jennifer. 2011. Political Repression: Iron Fists, Velvet Gloves, and Diffuse Control. Annual Review of Sociology 37 (1):261-84.

El-Ghobashy, Mona. 2011. The Praxis of the Egyptian Revolution. Middle East Research and Information Project 41 (258):3-11.

Escribà-Folch, Abel. 2013. Repression, Political Threats, and Survival Under Autocracy. International Political Science Review 34 (5):543-60.

Fisher, Ronald A. 1957. Letter to the Editor: Alleged Dangers of Cigarette-Smoking. British Medical Journal 2:297-8.

Francisco, Ronald A. 1995. The Relationship Between Coercion and Protest An Empirical Evaluation in Three Coercive States. Journal of Conflict Resolution 39 (2):263-82.

Gelman, Andrew, and Guido Imbens. 2013. Why Ask Why? Forward Causal Inference and Reverse Causal Questions. Working Paper, National Bureau of Economic Research. Available from http:// www.nber.org/papers/w19614. Accessed 18 February 2016.

Gould, Roger V. 1991. Multiple Networks and Mobilization in the Paris Commune, 1871. American Sociological Review 56:716-29.

Gupta, Dipak K., Harinder Singh, and Tom Sprague. 1993. Government Coercion of Dissidents Deterrence or Provocation? Journal of Conflict Resolution 37 (2):301-9.

Hersh, Eitan D. 2013. Long-Term Effect of September 11 on the Political Behavior of Victims' Families and Neighbors. Proceedings of the National Academy of Sciences 110 (52):20959-63.

Heydemann, Steven. 2013. Tracking the "Arab Spring": Syria and the Future of Authoritarianism. Journal of Democracy 24 (4):59-73.

Hoffman, Michael, and Amaney A. Jamal. 2012. The Youth and the Arab Spring: Cohort Differences and Similarities. Middle East Law and Governance 4:168-88.

Jamal, Amaney A., and Mark Tessler. 2008. Attitudes in the Arab World. Journal of Democracy 19 (1):97-110.

Jasper, James M. 2011. Emotions and Social Movements: Twenty Years of Theory and Research. Annual Review of Sociology 37 (1):285-303.

Kocher, Matthew Adam, Thomas B. Pepinsky, and Stathis N. Kalyvas. 2011. Aerial Bombing and Counterinsurgency in the Vietnam War. American Journal of Political Science 55 (2):201-18.

Kuran, Timur. 1991. Now Out of Never: The Element of Surprise in the East European Revolution of 1989. World Politics 44:7-48. 
Leenders, Reinoud, and Steven Heydemann. 2012. Popular Mobilization in Syria: Opportunity and Threat, and the Social Networks of the Early Risers. Mediterranean Politics 17 (2):139-59.

Lichbach, Mark Irving. 1987. Deterrence or Escalation? The Puzzle of Aggregate Studies of Repression and Dissent. Journal of Conflict Resolution 31 (2):266-97.

Lyall, Jason. 2009. Does Indiscriminate Violence Incite Insurgent Attacks? Evidence from Chechnya. Journal of Conflict Resolution 53 (3):331-62.

Lynch, Marc. 2011. After Egypt: The Limits and Promise of Online Challenges to the Authoritarian Arab State. Perspectives on Politics 9 (2):301-10.

McAdam, Doug. 1999. Political Process and the Development of Black Insurgency, 1930-1970. Chicago, IL: University of Chicago Press.

McAdam, Doug, Sidney G. Tarrow, and Charles Tilly. 2001. Dynamics of Contention. Cambridge: Cambridge University Press.

Makiya, Kanan. 1998. Republic of Fear: The Politics of Modern Iraq. Berkeley: University of California Press.

Oberschall, Anthony. 1973. Social Conflict and Social Movements. Englewood Cliffs, NJ: Prentice-Hall.

Opp, Karl-Dieter. 1994. Repression and Revolutionary Action East Germany in 1989. Rationality and Society 6 (1):101-38.

Opp, Karl-Dieter, and Wolfgang Roehl. 1990. Repression, Micromobilization, and Political Protest. Social Forces 69 (2):521-47.

Parkinson, Sarah Elizabeth. 2013. Organizing Rebellion: Rethinking High-Risk Mobilization and Social Networks in War. American Political Science Review 107 (3):418-32.

Petersen, Roger D. 1993. A Community-Based Theory of Rebellion. European Journal of Sociology 34:41-78.

- 2002. Understanding Ethnic Violence: Fear, Hatred, and Resentment in Twentieth-Century Eastern Europe. Cambridge: Cambridge University Press.

Pierskalla, Jan Henryk. 2010. Protest, Deterrence, and Escalation: The Strategic Calculus of Government Repression. Journal of Conflict Resolution 54 (1):117-45.

Popkin, Samuel L. 1989. Political Entrepreneurs and Peasant Movements in Vietnam. In Rationality and Revolution, edited by Michael Johnson, 9-62. Cambridge: Cambridge University Press.

Rasler, Karen. 1996. Concessions, Repression, and Political Protest in the Iranian Revolution. American Sociological Review 61 (1):132-52.

Ritter, Emily Hencken, and Courtney R. Conrad. 2013. Let the Rain Settle It: Estimating the Effect of Dissent on Repression. Paper Presented at the Annual Meeting of the Midwest Political Science Association, 11-14 April, Chicago IL.

Samuels, David J., and Cesar Zucco Jr. 2012. Using Facebook as a Subject Recruitment Tool for SurveyExperimental Research. SSRN eLibrary. Available from http://papers.ssrn.com/sol3/papers.cfm? abstract_id=2101458. Accessed 18 February 2016.

Schneider, Mark, and Paul Teske. 1992. Toward a Theory of the Political Entrepreneur: Evidence from Local Government. American Political Science Review 86 (3):737-47.

Schulz, Kenneth F, and David A Grimes. 2002. Case-Control Studies: Research in Reverse. The Lancet 359 (9304):431-4.

Siegel, David A. 2011. When Does Repression Work? Collective Action in Social Networks. The Journal of Politics 73 (4):993-1010.

Skocpol, Theda. 1979. States and Social Revolutions: A Comparative Analysis of France, Russia, and China. Cambridge: Cambridge University Press.

Snow, David A., Louis A. Zurcher Jr., and Sheldon Ekland-Olson. 1980. Social Networks and Social Movements: A Microstructural Approach to Differential Recruitment. American Sociological Review 45 (5):787-801.

Staggenborg, Suzanne. 1991. The Pro-Choice Movement: Organization and Activism in the Abortion Conflict. Oxford: Oxford University Press.

Tarrow, Sidney. 1994. Power in Movement: Social Movements, Collective Action and Politics. Cambridge: Cambridge University Press. 
Tilly, Charles. 1978. From Mobilization to Revolution. New York: McGraw-Hill.

Wedeen, Lisa. 2013. Ideology and Humor in Dark Times: Notes from Syria. Critical Inquiry 39 (4): 841-73.

Weyland, Kurt. 2012. The Arab Spring: Why the Surprising Similarities with the Revolutionary Wave of 1848? Perspectives on Politics 10 (4):917-34.

Wood, Elisabeth Jean. 2003. Insurgent Collective Action and Civil War in El Salvador. Cambridge: Cambridge University Press. 